\title{
Phlebitis associated with peripheral intravenous catheters in adults admitted to hospital in the Western Brazilian Amazon*
}

\author{
Flebite associada a cateteres intravenosos periféricos em adultos \\ internados em hospital da Amazônia Ocidental Brasileira \\ Flebitis asociadas con catéteres intravenosos periféricos en adultos \\ ingresados en hospital de la Amazonía Occidental Brasileña
}

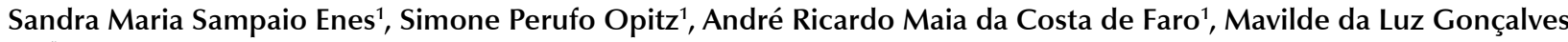
Pedreira $^{2}$

How to cite this article:

Enes SMS, Opitz SP, Faro ARMC, Pedreira MLG. Phlebitis associated with peripheral intravenous catheters in adults admitted to hospital in the Western Brazilian Amazon. Rev Esc Enferm USP. 2016;50(2):261-269. DOI: http://dx.doi.org/10.1590/S0080-623420160000200012

* Extracted from the dissertation "Complicações relacionadas ao uso de cateteres intravenosos periféricos em pacientes adultos internados em um hospital de ensino na Amazônia Ocidental Brasileira", Programa de Pósgraduação em Enfermagem, Universidade Federal de São Paulo, 2014

${ }^{1}$ Universidade Federal do Acre, Rio Branco, AC, Brazil.

${ }^{2}$ Universidade Federal de São Paulo, Escola Paulista de Enfermagem, Departamento de Enfermagem Pediátrica, São Paulo, SP, Brazil.

\begin{abstract}
Objective: To identify the presence of phlebitis and the factors that influence the development of this complication in adult patients admitted to hospital in the western Brazilian Amazon. Method: Exploratory study with a sample of 122 peripheral intravenous catheters inserted in 122 patients in a medical unit. Variables related to the patient and intravenous therapy were analyzed. For the analysis, we used chi-square tests of Pearson and Fisher exact test, with 5\% significance level. Results: Complication was the main reason for catheter removal $(67.2 \%)$, phlebitis was the most frequent complication (31.1\%). The mean duration of intravenous therapy use was 8.81 days in continuous and intermittent infusion $(61.5 \%)$, in $20 \mathrm{G}$ catheter $(39.3 \%)$, inserted in the dorsal hand vein $\operatorname{arc}(36.9 \%)$, with mean time of usage of 68.4 hours. The type of infusion $(p=0.044)$ and the presence of chronic disease $(p=0.005)$ and infection $(p=0.007)$ affected the development of phlebitis. Conclusion: There was a high frequency of phlebitis in the sample, being influenced by concomitant use of continuous and intermittent infusion of drugs and solutions, and more frequent in patients with chronic diseases and infection.
\end{abstract}

\section{DESCRIPTORS}

Phlebitis; Catheterization, Peripheral; Infusions, Intravenous; Inpatients; Nursing Care. 


\section{INTRODUCTION}

Intravenous therapy (IVT) is an essential intervention, frequently performed in health institutions ${ }^{(1)}$. The aim is to promote the distribution of fluids in the circulatory system, blood components, parenteral nutrition and intravenous action of drugs and others with low bioavailability when administered by other routes, in situations of intensive, emergency, perioperative and clinical care ${ }^{(2)}$.

To perform the IVT, a catheter needs to be inserted into a vein. There are several types of catheters used in clinical practice, peripheral intravenous catheters (PIC) are the most frequently used, since they provide access to the vascular system faster, are less invasive and less complex, estimated to be inserted in approximately one third of patients admitted to hospitals ${ }^{(3-5)}$.

Although the use of PIC is associated with many therapeutic benefits, it may be related to the development of local and systemic complications such as extravasation, infiltration, hematoma, infection and phlebitis ${ }^{(6-8)}$. The incidence of systemic infections related to PIC is low, and is rarely described, but is frequently associated with phlebitis ${ }^{(3,9)}$.

Phlebitis is one of the most frequent and severe local complications related to PIC use, characterized by inflammation of the vein wall with symptoms in variables degrees of edema, pain and erythema around the catheter insertion site or along the blood vessels, with the possible prognostic towards a palpable fibrous cord, and intense redness, tenderness and fever. It may be classified, in accordance with the predisposing factors of complication in mechanical phlebitis, resulting from the trauma caused by PIC in the vessel wall during the puncturing movement or during PIC use; chemical phlebitis, when there are relationship with infusion fluids or solutions with low solubility, extreme $\mathrm{pH}$ or high osmolarity, or due to the presence of small particles in the solution; and infectious-related phlebitis contamination of solutions and aseptic technique misconduct during insertion and PIC handling devices and solutions ${ }^{(1,5-6,10-12)}$.

Several studies describe the risk factors related to the development of phlebitis, but the results are conflicting depending on the population studied and the research methods. Some authors ${ }^{(3,13)}$ verified as risk factors: being female, the catheter size, anatomical location, catheter used for longer than 48 hours and the performance of rapid infusions of drugs with high osmolarity. However, another study ${ }^{(14)}$ did not identify the factors: being female and the catheter size as risk factors. A research ${ }^{(15)}$ showed no influence on the size and PIC insertion time in phlebitis, however, there was a relationship with the need for PIC reinsertion and use of certain substances such as potassium chloride, antibiotics, amiodarone hydrochloride, and diltiazem hydrochloride.

Regarding the frequency of complications, researches show very different rates, ranging from zero to over $50 \%$. A research that assessed 952 PIC in adults showed that 18.9\% of PIC had been removed due to the occurrence of phlebitis $^{(16)}$. In a study conducted in Turkey, with 439 catheters inserted in 103 adult patients, the occurrence of phlebitis was $41.2 \%{ }^{(6)}$; similar study in Brazil analyzed 234 insertions of catheters and identified presence of phlebitis in $55.6 \%$ of the PIC analyzed ${ }^{(17)}$.

When developing phlebitis during IVT infusion, the patient can require an early withdrawal of the PIC and reinsertion elsewhere. This situation leads to discontinuation of therapy and imposes stress for patients, due to the need for multiple intravenous punctures and cause rising cost of care $^{(1,7)}$.

Like other health outcomes, the occurrence of phlebitis may be related to the care environment and the quality of nursing practice, thus the aim of this study is to identify the presence of phlebitis in patients with PIC admitted to a medical clinic of a hospital in the Western Brazilian Amazon, analyzing patient characteristics and the IVT that contribute to the occurrence of complications.

\section{METHOD}

This is an exploratory study conducted in the medical unit, with a capacity of 43 beds, in a teaching hospital located in the city of Rio Branco, Acre State. Patients were included in the research from the need for PIC insertion occurred in the study period, from September 2013 to February 2014, and this period determined by staff availability involved to collect daily data on a 24 -hour period. The sample consisted of adult patients who required PIC insertion in the study period, aged equal to or greater than 18 years, level of guidance preserved according to clinical assessment (temporal and spatial orientation), length of hospital stay less than 30 days and who agreed to participate in the study by signing the Informed consent form. The study excluded patients who already had a PIC inserted in other units at the time of admission to the studied unit. Thus, at the end of the data collection, a convenience sample of 122 patients was studied, emphasizing that it was decided not to include patients more than once in research.

The study met the ethical issues according to Resolution CNS No.466/2012 and was approved at the study site by the Research Ethics Committee of the Universidade Federal de São Paulo, under the Protocol No.296912.

The dependent variable was characterized as the presence of phlebitis, considered the outcome for the analysis of variables related to the patient, the IVT characteristics and related to the description of peripheral venipuncture (PVP) and use of PIC.

Phlebitis was measured from the daily clinical evaluation of PIC insertion sites, by applying the rating scale proposed by Infusion Nursing Society (INS) ${ }^{(11)}$, according to the categories: Grade 0 when there are no clinical signs of phlebitis; Grade 1 if there is erythema, with or without local pain; Grade 2 if there is erythema, with local pain and or swelling; Grade 3 is characterized by the presence of erythema, local pain and/or swelling with hardening and palpable fibrous cord; Grade 4 if there is presence of pain with erythema and edema, with hardening and palpable fibrous cord greater than $2.5 \mathrm{~cm}$ in length and purulent drainage ${ }^{(11)}$. It is noteworthy that the identification of Grade 0 (zero) of the scale was categorized as a negative measure of phlebitis variable. 
The variables selected for demographic characteristics were: age, gender, self-reported skin color and the presence of predisposing condition for complications, the latter variable being measured into categories that express situations related to patient that could be characterized as predisposing to the occurrence of complications related to use of PIC, identified from the medical, nursing diagnoses and nursing evolution, such as chronic disease, vascular disease, edema, hypovolemia, obesity, infection, and others.

Regarding the variables related to IVT characteristics, we sought to describe: Time of use of IVT (variable categorized retrospectively, according to the period of use of IVT, for which it was considered the time of initiation of intravenous therapy, it could be earlier than the PIC use start studied), IVT infusion type (categorized as continuous and intermittent) IVT infusion method (bolus, gravitational and/or infusion pump) type of fluid administered (solutions and/or drugs), number of solutions, number of drugs, presence and type of current risk treatment for complications in order to identify aspects related to current IVT that could be related to the occurrence of phlebitis, such as: use of prolonged IVT (more than 14 days), use of high infusion rate (greater than $150 \mathrm{ml} / \mathrm{h}$ ) of vesicant drugs with extreme $\mathrm{pH}$ (less than four or greater than nine) and osmolarity (greater than $400 \mathrm{mOsm} / \mathrm{L}$ ), or described by the manufacturer as being at risk for complications.

The following variables were selected to describe the PVP: type of catheter (on needle or needled) catheter caliber (24 gauge [G], 22G, 20G, 18G, etc.), anatomical location (hand, forearm, antecubital fossa, arm, etc.), catheter insertion site (dorsal venous arch of hand, basilic vein, cephalic vein, forearm median vein, median elbow vein, others), catheter fixation (microporous tape or tape), PVP professional performing (nurse or nursing technician) and PIC nursing care level (grade 0 , grade 1 or grade 2). The level of nursing care refers to the scale proposed by Lundgren, Jorfeldt and $\mathrm{Ek}^{(18)}$, describing the care provided during the insertion of PIC, as follows: Grade 0 - Satisfactory nursing care: good fixation and cleaning, and the patient did not report pain. Grade 1 - Unsatisfactory nursing care: inadequate fixation; loose or dirty and the patient reported pain. Grade 2 - Very poor nursing care: very inadequate fixation, patient reported pain and the device in situ for more than five days. It is noteworthy that the PIC insertion procedure adopted in the institution consists of skin antisepsis with $70 \%$ alcohol and the catheter fixation with hypoallergenic microporous tape or tape. The technique is, therefore, the fixation and stabilization of PIC, not performing bandage over the site of insertion into the PIC in the investigated institution. Regarding institutional protocol implemented at the study site, the PIC insertion was carried out by nurses and nursing technicians. The administration of IVT is also performed on a shared basis among the nursing team, following standardization of reconstitution, dilution, time and method of infusion of drugs and solutions advocated in the institution. In the study unit, the exchange of the PIC every 72 hours is recommended, however, it was identified that such a protocol was not consistently implemented.
The PIC insertion was considered the starting point for the follow-up and observation of the patient sample. The monitoring and follow-up time was different, as the usage time of the catheter was considered.

Data collection was performed through observation of patients with PIC, driven by a research instrument containing information relating to the measurement of the variables. The data collection instrument was previously tested. The observation of patients was performed daily, in the morning between 8:00a.m. and 12:00p.m. in the afternoon between 2:00p.m. and 6:00p.m. and in the evening between 8:00p.m. and 00:00a.m., and during the dawn between 02:00a.m. and 06:00a.m., including weekends and holidays.

The collected data were typed, a double check was performed, in a Microsoft Excel ${ }^{\circledast}$ spreadsheet 2007. Later, they were submitted to descriptive and inferential statistical analysis by using SPSS 13.0. For analysis of categorical variables, absolute and relative frequencies were calculated, median, first and third quartiles, means and standard deviations numeric variables, which are presented in tables. For categorical variables correlation analysis, we used the chi-square tests of Pearson and Fisher exact test, choosing significance levels $\leq 0.05$.

\section{RESULTS}

A total of 122 PIC were studied, inserted in 122 patients, $50 \%$ female and $50 \%$ male, with a mean age of $46.1( \pm 17.6)$ years, ranging from 18 to 89 years old. The most often selfreported color of skin was brown (57.3\%), followed by white and black. Regarding the predisposing condition for complications, the presence of chronic diseases was highlighted (60.7\%), followed by infection (26.2\%) (Table 1).

Table 1 - Characteristics of patients with PIC - Rio Branco, Acre, Brazil, 2014.

\begin{tabular}{|c|c|c|}
\hline Variables & $\mathbf{N}$ & $\%$ \\
\hline \multicolumn{3}{|l|}{ Age (years) } \\
\hline Up to 50 years old & 68 & 55.7 \\
\hline Over 50 years old & 54 & 44.3 \\
\hline Median (Q1 - Q3) & \multicolumn{2}{|c|}{$47(31-58)$} \\
\hline Mean & \multicolumn{2}{|c|}{46.1} \\
\hline Standard-deviation & \multicolumn{2}{|c|}{17.6} \\
\hline Minimum - Maximum & \multicolumn{2}{|c|}{$18-89$} \\
\hline \multicolumn{3}{|l|}{ Gender } \\
\hline Female & 61 & 50.0 \\
\hline Male & 61 & 50.0 \\
\hline \multicolumn{3}{|l|}{ Self-reported skin color } \\
\hline White & 27 & 22.1 \\
\hline Brown & 70 & 57.3 \\
\hline Black & 18 & 14.9 \\
\hline Red & 02 & 1.6 \\
\hline Yellow & 05 & 4.1 \\
\hline
\end{tabular}

continued.. 


\begin{tabular}{|c|c|c|}
\hline Variables & $\mathbf{N}$ & $\%$ \\
\hline \multicolumn{3}{|c|}{ Predisposing condition for complications } \\
\hline Yes & 104 & 85.2 \\
\hline No & 18 & 14.8 \\
\hline \multicolumn{3}{|c|}{ Type of predisposing condition (122) } \\
\hline \multicolumn{3}{|c|}{ Infection } \\
\hline Yes & 32 & 26.2 \\
\hline No & 90 & 73.8 \\
\hline \multicolumn{3}{|l|}{ Edema } \\
\hline Yes & 12 & 9.9 \\
\hline No & 110 & 90.1 \\
\hline \multicolumn{3}{|c|}{ Hypovolemia } \\
\hline Yes & 01 & 0.8 \\
\hline No & 121 & 99.2 \\
\hline \multicolumn{3}{|c|}{ Obesity } \\
\hline Yes & 05 & 4.1 \\
\hline No & 117 & 95.9 \\
\hline \multicolumn{3}{|c|}{ Chronic disease } \\
\hline Yes & 74 & 60.7 \\
\hline No & 48 & 39.3 \\
\hline \multicolumn{3}{|c|}{ Vascular disease } \\
\hline Yes & 07 & 5.7 \\
\hline No & 115 & 94.3 \\
\hline \multicolumn{3}{|l|}{ Other } \\
\hline Yes & 10 & 8.2 \\
\hline No & 112 & 91.8 \\
\hline
\end{tabular}

Legend: Q1 - $1^{\text {st }}$ Quartile; Q3 $-3^{\text {st }}$ Quartile.

The mean time of IVT use was $8.81( \pm 6.89)$ days, and $58.2 \%$ of patients used them for up to seven days, a number that corresponds to the median of days of IVT. Regarding infusion, the majority (61.5\%) had the combination of continuous and intermittent type, through bolus and gravitational infusion methods (74.6\%), for administration of solutions and drugs (82.0\%), one solution was predominantly used (68.0\%) and more than two drugs (81.1\%). It was found that out of the 122 patients studied, 80 (65.6\%) had some type of treatment at risk for complications, we highlight the use of drugs with extreme $\mathrm{pH}(62.5 \%)$ and vesicant $(62.5 \%)$ as well as the use of IVT for a prolonged time (42.5\%) (Table 2).

Table 2 - Characteristics of intravenous therapy of patients with PIC - Rio Branco, Acre, Brazil, 2014.

\begin{tabular}{lcc}
\hline Variables & N & $\%$ \\
\hline Time of IVT use (days) & & \\
Up t 7 days & 71 & 58.2 \\
Over 7 days & 51 & 41.8 \\
Median (Q1-Q3) & $7(4-11.25)$ \\
Mean & 8.81 \\
Standard-deviation & 6.89 \\
Minimum-Maximum & $0-32$ \\
\hline
\end{tabular}

continued... ...continuation

\begin{tabular}{|c|c|c|}
\hline Variables & $\mathbf{N}$ & $\%$ \\
\hline \multicolumn{3}{|l|}{ IVT type of infusion } \\
\hline Continuous & 03 & 2.5 \\
\hline Intermitent & 44 & 36.0 \\
\hline Continuous and intermitent & 75 & 61.5 \\
\hline \multicolumn{3}{|l|}{ IVT infusion method } \\
\hline Bolus & 22 & 18.0 \\
\hline Gravitational & 08 & 6.6 \\
\hline Infusion pump & 01 & 0.8 \\
\hline Bolus and Gravitational & 91 & 74.6 \\
\hline \multicolumn{3}{|l|}{ Type of fluid administered } \\
\hline Solution & 03 & 2.5 \\
\hline Drugs & 19 & 15.5 \\
\hline Solutions and drugs & 100 & 82.0 \\
\hline \multicolumn{3}{|l|}{ Number of solutions } \\
\hline One solution & 83 & 68.0 \\
\hline More than one solution & 39 & 32.0 \\
\hline \multicolumn{3}{|l|}{ Number of drugs } \\
\hline Up to two drugs & 23 & 18.9 \\
\hline More than two drugs & 99 & 81.1 \\
\hline \multicolumn{3}{|c|}{ Current treatment of risk for complications } \\
\hline Yes & 80 & 65.6 \\
\hline No & 42 & 34.4 \\
\hline
\end{tabular}

Type of current risk treatment $=(\mathbf{8 0})$

Prolonged intravenous therapy

Yes

$34 \quad 42.5$

No

$46 \quad 57.5$

Use of vesicant drugs

Yes

$50 \quad 62.5$

No

$30 \quad 37.5$

Drugs with extreme pH

$\begin{array}{lll}\text { Yes } & 50 & 62.5\end{array}$

$\begin{array}{lll}\text { No } & 30 & 37.5\end{array}$

Drugs with high osmolarity

$\begin{array}{lll}\text { Yes } & 15 & 18.7\end{array}$

$\begin{array}{lll}\text { No } & 65 & 81.3\end{array}$

High rate of infusion

$\begin{array}{lll}\text { Yes } & 26 & 32.5\end{array}$

$\begin{array}{lll}\text { No } & 54 & 67.5\end{array}$

Legend: Q1 - $1^{\text {st }}$ Quartile; Q3 - 3 ${ }^{\text {rd }}$ Quartile.

The most used type of catheter was on needle (99.0\%) and $20 \mathrm{G}$ caliber (39.3\%), which were mainly placed on the forearm (53.3\%) and the veins of the dorsal venous arch of the hand $(36,9 \%)$, cephalic $(25.4 \%)$, median forearm (14.7\%) and basilic (13.1\%). The catheters were fixed with a tape (98.4\%) and nursing technicians were responsible for almost all (91.8\%) of PVP. The level of nursing care was Grade 1 (73.0\%), which represents nursing care judged as 
inadequate. The mean time of admission of PIC was nearly three days (68.4 hours) with $80.3 \%$ remaining inserted for up to 96 hours and $19.7 \%$ for more than 96 hours (Table 3 ).

Table 3 - Characteristics of peripheral venous puncture of patients with PIC - Rio Branco, Acre, Brazil, 2014.

\begin{tabular}{|c|c|c|}
\hline Variables & $\mathbf{N}$ & $\%$ \\
\hline \multicolumn{3}{|l|}{ Type of catheter } \\
\hline On needle & 121 & 99.0 \\
\hline Needled & 01 & 1.0 \\
\hline \multicolumn{3}{|l|}{ Caliber of the catheter } \\
\hline $24 \mathrm{G}$ & 17 & 13.9 \\
\hline $22 \mathrm{G}$ & 38 & 31.1 \\
\hline $20 \mathrm{G}$ & 48 & 39.3 \\
\hline $18 \mathrm{G}$ & 18 & 14.7 \\
\hline Other & 01 & 1.0 \\
\hline \multicolumn{3}{|l|}{ Anatomical position } \\
\hline Hand & 45 & 36.9 \\
\hline Forearm & 65 & 53.3 \\
\hline Antecubital fossa & 05 & 4.1 \\
\hline Arm & 06 & 4.9 \\
\hline Others & 01 & 0.8 \\
\hline \multicolumn{3}{|l|}{ Catheter insertion site } \\
\hline Dorsal venous arch of hand & 45 & 36.9 \\
\hline Basilic vein & 16 & 13.1 \\
\hline Cephalic vein & 31 & 25.4 \\
\hline Median vein of forearm & 18 & 14.7 \\
\hline Median vein of elbow & 08 & 6.6 \\
\hline Others & 04 & 3.3 \\
\hline \multicolumn{3}{|l|}{ Fixation of the catheter } \\
\hline Microporous tape & 02 & 1.6 \\
\hline Adhesive tape & 120 & 98.4 \\
\hline \multicolumn{3}{|l|}{ Professional performing PVP } \\
\hline Nurse & 10 & 8.2 \\
\hline Nurse technician & 112 & 91.8 \\
\hline \multicolumn{3}{|l|}{ Nursing care level } \\
\hline Grade 0 & 26 & 21.3 \\
\hline Grade 1 & 89 & 73.0 \\
\hline Grade 2 & 07 & 5.7 \\
\hline \multicolumn{3}{|c|}{ Length of time with the catheter (hours) } \\
\hline Up to 96 hours & 98 & 80.3 \\
\hline Over 96 hours & 24 & 19.7 \\
\hline Median (Q1-Q3) & \multicolumn{2}{|c|}{$57(35-89.75)$} \\
\hline Mean & \multicolumn{2}{|c|}{68.4} \\
\hline Standard-deviation & \multicolumn{2}{|c|}{46.28} \\
\hline Minimum-Maximum & \multicolumn{2}{|c|}{$11-283$} \\
\hline
\end{tabular}

Legend: Q1 $-1^{\text {st }}$ Quartile; Q3 $-3^{\text {rd }}$ Quartile.

Phlebitis was responsible for 38 complications (31.1\%), and Grade 1 had highest proportion (65.8\%). It was observed that $34.2 \%$ of patients developed more severe cases of this complication, $23.7 \%$ from Grade 2; 7.9\% from Grade 3; and $2.6 \%$ from Grade 4.

Table 4 shows the presence of phlebitis associated with the use of PIC and current characteristics of IVT, with influence on complications related to catheter.

In Table 4 , we present significant relationship between phlebitis and type of infusion ( $p=0.044)$, and the combined use of continuous and intermittent infusion had greater occurrence compared with phlebitis. Infection and chronic disease had a significant association with the development of phlebitis ( $\mathrm{p}=0.007$ and 0.005 , respectively).

Table 4 - Presence of phlebitis associated with the use of peripheral intravenous catheters and characteristics of intravenous therapy with influence on complications related to PIC - Rio Branco, Acre, Brazil, 2014.

\begin{tabular}{l|ccccccc}
\hline & \multicolumn{6}{c}{ Phlebitis } \\
\cline { 2 - 6 } Variables & \multicolumn{2}{c}{ Yes } & \multicolumn{1}{c}{ No } & \multicolumn{2}{c}{ Total } & \\
\cline { 2 - 6 } & N & $\%$ & N & $\%$ & N & $\%$ & \\
\hline
\end{tabular}

Time of use of IVT

$0.964^{\mathrm{a}}$

$\begin{array}{lllllll}\text { Up to } 7 \text { days } & 22 & 18.0 & 49 & 40.2 & 71 & 58.2\end{array}$

$\begin{array}{lllllll}\text { Over } 7 \text { days } & 16 & 13.1 & 35 & 28.7 & 51 & 41.8\end{array}$

Infusion type

Continuous

$0.044^{\mathrm{b}}$

Intermitent

Continuous and intermitent

$\begin{array}{llllll}01 & 0.8 & 02 & 1.7 & 03 & 2.5\end{array}$

Infusion method

$\begin{array}{llllll}08 & 6.6 & 36 & 29.4 & 44 & 36.0\end{array}$

$\begin{array}{llllll}29 & 23.8 & 46 & 37.7 & 75 & 61.5\end{array}$

$\begin{array}{llllllll}\text { Infusion pump } & 01 & 8.0 & 0 & - & 01 & 0.8\end{array}$

Bolus

Gravitational

$\begin{array}{llllll}04 & 3.3 & 18 & 14.7 & 22 & 18.0\end{array}$

Bolus and gravitational

$\begin{array}{llllll}02 & 1.7 & 06 & 4.9 & 08 & 6.6\end{array}$

$\begin{array}{llllll}31 & 24.4 & 60 & 50.2 & 91 & 74.6\end{array}$

Fluid types

Solution

Drugs

Solution and drugs

Number of drugs

$\begin{array}{lllllll}\text { Up to two drugs } & 05 & 4.1 & 18 & 14.8 & 23 & 18.9\end{array}$

$\begin{array}{lllllll}\text { Over two drugs } & 33 & 27.1 & 66 & 54.0 & 99 & 81.1\end{array}$

Current treatment risk $0.392^{\mathrm{a}}$

$\begin{array}{lllllll}\text { Yes } & 27 & 22.1 & 53 & 43.5 & 80 & 65.6\end{array}$

$\begin{array}{lllllll}\text { No } & 11 & 9.0 & 31 & 25.4 & 42 & 34.4\end{array}$

Nursing level of care $\quad 0.054^{\mathrm{b}}$

$\begin{array}{lllllll}\text { Grade } 0 & 04 & 3.3 & 22 & 18.0 & 26 & 21.3\end{array}$

$\begin{array}{lllllll}\text { Grade } 1 & 31 & 25.4 & 58 & 47.6 & 89 & 73.0\end{array}$

$\begin{array}{lllllll}\text { Grade } 2 & 03 & 2.4 & 04 & 3.3 & 07 & 5.7\end{array}$

Length of hospital stay

$0.796^{b}$

$\begin{array}{lllllll}\text { Up to } 96 \text { hours } & 30 & 24.5 & 68 & 55.7 & 98 & 80.3\end{array}$

$\begin{array}{lllllll}\text { Over } 96 \text { hours } & 08 & 6.6 & 16 & 13.1 & 24 & 19.7\end{array}$

continued... 


\begin{tabular}{|c|c|c|c|c|c|c|c|}
\hline \multirow{3}{*}{ Variables } & \multicolumn{7}{|c|}{ Phlebitis } \\
\hline & \multicolumn{2}{|c|}{ Yes } & \multicolumn{2}{|c|}{ No } & \multicolumn{2}{|c|}{ Total } & \multirow{2}{*}{$\mathbf{P}$} \\
\hline & $\mathbf{N}$ & $\%$ & $\mathbf{N}$ & $\%$ & $\mathbf{N}$ & $\%$ & \\
\hline Infection & & & & & & & $0.007^{\mathrm{a}}$ \\
\hline Yes & 16 & 13.1 & 16 & 13.2 & 32 & 26.2 & \\
\hline No & 22 & 18.0 & 68 & 55.7 & 90 & 73.8 & \\
\hline Chronic disease & & & & & & & $0.005^{\mathrm{a}}$ \\
\hline Yes & 16 & 13.1 & 58 & 47.6 & 74 & 60.7 & \\
\hline No & 22 & 18.0 & 26 & 21.3 & 48 & 39.3 & \\
\hline
\end{tabular}

${ }^{\mathrm{a}}$ Chi-square test; ${ }^{\mathrm{b}}$ Fisher's exact test.

\section{DISCUSSION}

We found higher frequency of phlebitis $31.1 \%$, well above the $5 \%$ ratio considered as the standard accepted by the recommendations of the INS, for both adults and children $^{(11)}$. Some studies point out that the occurrence of phlebitis can be very different in each case, depending on the definition of phlebitis, method, variables and studied population, ranging from $1.7 \%$ to $55.6 \%{ }^{(17,19)}$. The reasons may be related to the different frequencies described by the different sample sizes and types of study. It may also be compared to the methods used to analyze the presence of phlebitis, as well as the difficulty of standardizing the diagnosis and the severity, which implies observing and considering associated signs and symptoms. Furthermore, the inflammatory response, mainly in frail elderly, may be impaired and make the signs and symptoms subtler.

The frequency of phlebitis found in this study shows some similarity to the rates found in other studies with the adult population, between $17.6 \%$ and $24.7 \%^{(12,20)}$, and proved to be lower than the values of $43 \%$ and $54.5 \%$ found in other studies ${ }^{(4,14)}$.

The evaluation of the degree of phlebitis showed that in $2.6 \%$ of the studied sites, hardening of the vein, palpable fibrous cord and purulent drainage, as well as more advanced degree of this complication were observed. The other evaluations indicated less severe forms, especially Grade 1 (65.8\%) over Grade 2 (23.7\%). These findings are consistent with those obtained in other studies that also used the INS scale $\mathrm{e}^{(11)}$ to assess the severity of phlebitis. A study in a neurosurgical unit in the city of São Paulo, showed greater frequency of Grade $1(50 \%)$ and Grade $2(43.7 \%)^{(21)}$. Investigating occurrence of phlebitis in a medical unit of a hospital in Brasilia, researchers found that the presence of phlebitis in Grade 1 (46.2\%) and Grade 2 (40\%) were predominant ${ }^{(17)}$.

Results of research conducted in other countries also show increased less severe phlebitis frequency. In a cohort study with 967 adult patients in Barcelona, it was observed a higher frequency of phlebitis Grade $1(77.6 \%)$ and Grade 2 (22\%). A quasi-experimental research type, held in a private hospital in Barcelona, found higher incidence of phlebitis Grade $1(50 \%)$ and Grade $2(35 \%)^{(3,22)}$.

A review study conducted with a sample of 679 adults with PIC described 25 (3.7\%) occurrences of phlebitis, most were considered as Grade $1^{(23)}$. A descriptive research conducted in Turkey found 54.5\% occurrences of phlebitis and Grade 1 was also the most frequently observed ${ }^{(14)}$.

In this investigation, complications were more frequently in female patients, who self-reported brown skin color and who were under the age of 50 years. Among the characteristics related to the patient, none showed significant influence on the occurrence of complications associated with the use of PIC, a result that corroborates other studies in the $\operatorname{area}^{(14,15,24)}$.

Regarding the characteristics of PVP, there was no significant influence of most of the variables studied, a prevalence of complications was identified in catheters inserted in the forearm (34.4\%), followed by the back of the hand $(23.8 \%)$ in veins of the dorsal venous arch (23.8\%), cephalic vein (16.4\%) and median of the forearm (10.6\%), inserted by nursing staff with catheters on needle $20 \mathrm{G}$, fixed with tape. A cohort study also showed no statistical relationships between anatomical location, catheter size and occurrence of phlebitis ${ }^{(24)}$.

From the variables associated to IVT, there were no significant associations with the development of phlebitis, although other studies show that the administration of drugs with extremes $\mathrm{pH}$ and osmolarity may feature higher risk for the development of phlebitis ${ }^{(8,25)}$. Some authors claim that several drugs, such as antibiotics, phenytoin and mannitol may predispose the occurrence of phlebitis, reducing PIC time of use (14,25-26). $^{2}$

We identified shorter length of use of the device in patients with phlebitis, when compared to those who did not have this problem, however, there were no significant associations between phlebitis and longer PIC use. A cohort study showed a higher risk for phlebitis in patients who remained with PIC for more than 72 hours ${ }^{(17)}$. Another study revealed that the PIC use for more than 72 hours increased by up to four times the chance of developing phlebitis compared to the catheters use for less than 72 hours ${ }^{(4)}$. However, another investigation showed that there was no significant result in the development of phlebitis in patients with PIC inserted for a period greater than 96 hours when compared to those that remained with the catheter for equal to or less than 72 hours ${ }^{(20)}$. Recent studies have reported no benefits for the exchange of catheters every 72 or 96 hours when compared to the clinically indicated exchange ${ }^{(16,27-28)}$. The Centers for Disease Control and Prevention ${ }^{(7)}$ suggests that PIC must not be changed more than once every 72 to 96 hours in adult patients, so this is an unresolved question about the exchange of PIC only in the presence of signs of complications, understanding that we lack evidences to refute the correlation between time of PIC use and occurrence of phlebitis.

The infusion type showed association on the occurrence of phlebitis $(\mathrm{p}=0.044)$; the combination of continuous and intermittent type was associated to the higher incidence of phlebitis (23.8\%). Cohort study conducted with a sample of 60 patients showed that the type of intermittent infusion was the most predisposed occurrence of phlebitis associated with the PIC ${ }^{(21)}$. However, other studies have shown predominance 
of continuous infusion type influencing the development of PIC complications ${ }^{(4,29)}$. The use of intermittent infusion may increase the chances of complications related to PIC, as a result of greater manipulation of the catheter ${ }^{(14)}$.

It was not found statistically significant difference between the condition of the patient and the occurrence of complications $(p>0.05)$ in this study except for the presence of chronic disease $(p=0.005)$ and infection $(p=0.007)$. Patients with these health conditions showed $13.1 \%$ of the phlebitis occurrences. This finding corroborates another study conducted in adults and children, in which it was found that patients with infectious diseases, burns or diabetes mellitus have up to seven times more risk of developing phlebitis ${ }^{(30)}$.

It is noteworthy that this study presents phlebitis occurrence associated to PIC use, in a region of Brazil where we can find extreme weather conditions of humidity and high temperatures. The equatorial climate can be a predisposing factor for complications related to PIC use, especially by observing, more often, the loss of PIC stability by displacement of fixing materials, due to the sweating of the skin and high humidity, as well the fact that it can contribute to higher bacterial colonization. Thus, we describe again that health institutions in this region, nurses usually do not adopt the performance of sterile dressings on the PIC insertion site. They use non-sterile tape in order to keep the catheter fixed for a longer period, due to dressings maintenance difficulty with semipermeable transparent tape, which is quickly detached. This may be a factor related to the high proportion of phlebitis identified in the patients studied.

This study has limitations resulting from the convenience sample which did not allow us to reach the power of the study, which can lead to identification of risk factors for the occurrence of phlebitis. Another aspect which makes comparisons difficult refers to the use of fixation technique, which makes difficult early identification of complications, as well as special work of nurses in performing the insertion of PIC. Despite being recommended, the implementation of aseptic technique in catheter insertion with subsequent completion of dressing over the insertion site, we identified site misconduct of aseptic technique in the study, in which the fixing use was done with contaminated tapes, reality also identified in other health institutions in the country, and that may be related to the results identified in this research. It also highlights the lack of periodic assessment protocols of insertion sites of catheters, to promote the maintenance of devices and early identification of signs of complications. It is evident, therefore, the need to apply knowledge to practice, and the development of intervention research to enable testing new nursing care to be implemented at the study site in order to change the unfavorable results, which may be related to the difficulty of maintaining dressings and fixation on the catheter insertion site for the special characteristics of humid climate of the region studied. Nevertheless, this research has the potential to contribute to advances in knowledge, by presenting ITV results, conducted in the country region that lacks research in nursing, providing grants for further studies aimed at improving the quality of nursing care, as well as the search for new forms of intervention in order to reduce the occurrence of complications and promote patient safety.

\section{CONCLUSION}

Complication was the main reason for PIC removal, phlebitis was the most frequent. Patients with systemic infection, patients with chronic diseases and those requiring continuous and intermittent infusion concomitant with the catheter had significantly higher frequency of phlebitis associated to PIC compared to those who did not have such characteristics.

\section{RESUMO}

Objetivo: Identificar a presença de flebite e os fatores que influenciam o desenvolvimento desta complicação em pacientes adultos internados em hospital da Amazônia Ocidental Brasileira. Método: Estudo exploratório, com amostra de 122 cateteres intravenosos periféricos instalados em 122 pacientes de uma unidade de clínica médica. Foram analisadas variáveis relacionadas ao paciente e à terapia intravenosa. Para a análise utilizaram-se os testes de Qui-quadrado de Pearson e Exato de Fisher, com nível de significância de 5\%. Resultados: A complicação foi o principal motivo da retirada do cateter (67,2\%), e a flebite a complicação mais frequente (31,1\%). O tempo médio de uso de terapia intravenosa foi de 8,81 dias, em infusão contínua e intermitente $(61,5 \%)$, em cateter calibre $20 \mathrm{G}$ $(39,3 \%)$, inseridos nas veias do arco dorsal da mão (36,9\%), com média de tempo de permanência de 68,4 horas. O tipo de infusão $(p=0,044)$ e a presença de doença crônica $(p=0,005)$ e de infecção $(p=0,007)$ influenciaram o desenvolvimento de flebite. Conclusão: Houve alta frequência de flebite na amostra estudada, sendo influenciada pelo emprego concomitante de infusão contínua e intermitente de fármacos e soluções, e mais frequente em pacientes com doenças crônicas e infecção.

\section{DESCRITORES}

Flebite; Cateterismo Periférico; Infusões Intravenosas; Pacientes Internados; Cuidados de Enfermagem.

\section{RESUMEN}

Objetivo: Identificar la presencia de flebitis y los factores que influencian el desarrollo de esta complicación en pacientes adultos ingresados en hospital de la Amazonía Occidental Brasileña. Método: Estudio exploratorio, con muestra de 122 catéteres intravenosos periféricos instalados en 122 pacientes de una unidad de clínica médica. Fueron analizadas variables relacionadas con el paciente y la terapia intravenosa. Para el análisis se utilizaron las pruebas de Chi cuadrado de Pearson y Exacta de Fisher, con nivel de significación del 5\%. Resultados: La complicación fue el principal motivo de la retirada del catéter $(67,2 \%)$, y la flebitis la complicación más frecuente $(31,1 \%)$. El tiempo medio de uso de terapia intravenosa fue de 8,81 días, en infusión continua e intermitente (61,5\%), en catéter calibre $20 \mathrm{G}(39,3 \%)$, insertados en las venas del arco dorsal de la mano $(36,9 \%)$, con promedio de tiempo de permanencia de 68,4 horas. El tipo de infusión $(\mathrm{p}=0,044)$ y la presencia de enfermedad crónica $(\mathrm{p}=0,005)$ y de infección $(\mathrm{p}=0,007)$ influenciaron el desarrollo de flebitis. 
Conclusión: Hubo alta frecuencia de flebitis en la muestra estudiada, siendo influenciada por el empleo concomitante de infusión continua e intermitente de fármacos y soluciones, y más frecuente en pacientes con enfermedades crónicas e infección.

DESCRIPTORES

Flebitis; Cateterismo Periférico; Infusiones Intravenosas; Pacientes Internos; Atención de Enfermería.

\section{REFERENCES}

1. Ho KHM, Cheung DSK. Guidelines on timing in replacing peripheral intravenous catheters. J Clin Nurs. 2012;21(11-12):1499-506.

2. Dychter SS, Gold DA, Carson D, Haller M. Intravenous therapy: a review of complications and economic considerations of peripheral access. J Infus Nurs.2012; 35(2):84-91.

3. Roca GM, Bertolo CB, Lopez PT, Samaranch GG, Ramirez MCA, Buqueras, JC et al. Assessing the influence of risk factors on rates and dynamics of peripheral vein phlebitis: an observational cohort study. Med Clin. 2012;139(5):185-91.

4. Furtado LCR. Maintenance of peripheral venous access and its impact on the development of phlebitis: a survey of 186 catheters in a general surgery department in Portugal. J Infus Nurs. 2011;34(6):382-90.

5. Jacinto AKL, Avelar AFM, Wilson AMMM, Pedreira MLG. Flebite associada a cateteres intravenosos periféricos em crianças: estudo de fatores predisponentes. Esc Anna Nery [Internet]. 2014 [citado 2015 maio 25];18(2):220-6. Disponível em: http://www.scielo.br/pdf/ean/ v18n2/1414-8145-ean-18-02-0220.pdf

6. Pasalioglu KB, Kaya H. Catheter indwell time and phlebitis development during peripheral intravenous catheter administration. Pakistan J Med Sci. 2014;30(4):725-30.

7. O'Grady NP, Alexander M, Burns LA, Dellinger EP, Garland J, Heard SO, et al. Guidelines for the prevention of intravascular catheterrelated infections. Clin Infect Dis [Internet]. 2011 [cited 2012 May 1];52(9):162-93. Available from: http://www.ncbi.nlm.nih.gov/pmc/ articles/PMC3106269/

8. Martins TS, Silvino ZR, Dias SL. Perfil da terapia intravenosa pediátrica em um hospital universitário e associação com a ocorrência de falhas infusionais: estudo quantitativo. Online Braz J Nurs [Internet]. 2010 [citado 2012 mao 10];9(2). Disponível em: http://www. objnursing.uff.br/index.php/nursing/article/view/3067/684

9. Cicolini G, Manzoli L, Simonetti V, Flacco ME, Comparcini D, Capasso L, et al. Phlebitis risk varies by peripheral venous catheter site and increases after 96 hours: a large multi-centre prospective study. J Adv Nurs. 2014;70(11):2539-49.

10. Silva GA, Priebe S, Dias FN. Benefits of establishing an intravenous team and the standardization of peripheral intravenous catheters. J Infus Nurs.2010;33(3):156-60.

11. Infusion Nurses Society. Infusion nursing standards of practice. J Infus Nurs. 2006;29(1 Suppl):S1-92.

12. Urbanetto JS, Rodrigues AB, Oliveira DJ, Dornelles FF, Rosa Filho JM, Gustavo AS, et al. Prevalência de flebites em pacientes adultos com cateter venoso periférico. Rev Enferm UFSM. 2011;1(3):440-8.

13. Maki DG, Ringer M. Risk factors for infusion-related phlebitis with small peripheral venous catheters: a randomized controlled trial. Ann Intern Med. 1991;114(10):845-54.

14. Uslusoy E, Mete S. Predisposing factors to phlebitis in patients with peripheral intravenous catheters: a descriptive study. J Am Acad Nurs Pract. 2008;20(4):172-80.

15. Gallant P, Schultz AA. Evaluation of a visual phlebitis scale for determining appropriate discontinuation of peripheral intravenous catheters. J Infus Nurs. 2006; 29(6):338-45.

16. Gonzales Lopes JL, Arribi VA, Fernadez del Palacio E, Olivares Corral J, Benedicto Martí C, Herrera Portal P. Indwell times, complications and costs of open vs closed safety peripheral intravenous catheters: a randomized study. J Hosp Infect. 2014;86(2):117-26.

17. Abdul-Hak CKI, Barros AF. Incidência de flebite em uma Unidade de Clínica Médica. Texto Contexto Enferm [Internet]. 2014 [citado 2015 maio 31];23(3):633-8. Disponível em: http://www.scielo.br/pdf/tce/v23n3/pt_0104-0707-tce-23-03-00639.pdf

18. Lundgren A, Jorfeldt L, Ek AC. The care and handling of peripheral intravenous cannulae on 60 surgery and internal medicice patients: an observation study. J Adv Nurs. 1993;18(6):963-97.

19. Batalha LMC, Costa LPS, Almeida DMG, Lourenço PAA, Gonçalves AMFM, Teixeira ACG. Fixação de cateteres venosos periféricos em crianças: estudo comparativo. Esc Anna Nery. 2010;14(3):511-8.

20. Abolfotouh MA, Salam M, Bani-Mustafa A, White D, Balkhy HH. Prospective study of incidence and predictors of peripheral intravenous catheter-induced complications. Ther Clin Risk Manag. 2014;8(10):993-1001 .

21. Ferreira LR, Pedreira MLG, Diccini S. Flebite no pré e pós-operatório de pacientes neurocirúrgicos. Acta Paul Enferm. 2007;20(1):30-6.

22. Mestre G, Berbel C, Tortajada P, Alarcia M, Coca R, Fernández MM, et al. Successful multifaceted intervention aimed to reduce short peripheral venous catheter-related adverse events: a quasiexperimental cohort study. Am J Infect Control. 2013; 41(6):520-6.

23. Powell J, Tarnow KG, Perucca R. The relationship between peripheral intravenous catheter indwell time and the incidence of phlebitis. J Infus Nurs. 2008;31(1):39-45.

24. Fang L, Fang SH, Chung YH. Factors affecting the unplanned peripheral reinsertion in pediatric patiernts from a teaching hospital in Taiwan. J Infus Nurs. 2011;34(6):366-72.

25. Benaya A, Schwartz Y, Kory R, Ynnon AM, Ben-Chetrit E. Relative incidence of phlebitis associated with peripheral intravenous catheters in the lower versus upperextremities. Eur J Clin Microbiol Infect Dis. 2015;34(5):913-6. 
26. Shenoy S, Karunakar BP. Factors influencing the peripheral venous catheter survival in critically III children in a pediatric intensive care unit. Indian J Pediatr. 2014; 81(12):1293-6.

27. Rickard CM, Webster J, Wallis MC, Marsh N, McGrail MR, French V, et al. Routine versus clinically indicated replacement of peripheral intravenous catheters: a randomised controlled equivalence trial. Lancet. 2012;380(9847):1066-74.

28. Webster J, Osborne S, Rickard C, Hall J. Clinically-indicated replacement versus routine replacement of peripheral venous catheters. Cochrane Database Syst Rev. 2010;(3):CD007798.

29. Lee WL, Chen HL, Tsai TY, Lai IC, Chang WC, Huang CH, et al. Risk factors for peripheral intravenous catheter infection in hospitalized patients: a prospective study of 3165 patients. Am J Infect Control. 2009;37(8):683-6.

30. Nassaji-Zafareh M, Ghorbani R. Peripheral intravenous catheter-related phlebitis and related risk factors. Singapore Med J. 2007;48(8):733-6. 